\title{
Miscarriages of Justice in Canada: Causes, Responses, Remedies
}

\author{
By Dr. Kathryn M. Campbell, Professor of Criminology, University of Ottawa, Canada \\ Toronto: University of Toronto Press, 2018
}

\author{
Reviewed by Jonathan Freedman \\ Emeritus Professor of Psychology, University of Toronto, Canada \\ Past President and Treasurer of Innocence Canada
}

This book covers a great deal of material related to wrongful conviction or as the book terms it miscarriages of justice. As the subtitle says, the book deals with the causes, responses, and remedies. There is a wealth of information in the book that could serve as an introduction to this very important topic. It would be appropriate as a textbook for a course for undergraduates or even graduates or law students who want to learn about what causes wrongful convictions and how to prevent them from happening in the future. In that sense the book is a successful venture written by a very knowledgeable person and presented in a logical, thorough way.

It also contains some useful tables dealing with various aspects of wrongful convictions. It lists many of the known wrongful convictions in Canada, when they occurred, how long the people served and what compensation they received, if any. There are other tables that present the factors involved in wrongful convictions and the relevant commissions and the guidelines for judges. All of these tables are in the Canadian context. Even those who are already familiar with the issue of wrongful convictions and who might not need most of this book to inform them will find these table helpful. They are a definite contribution.

The author, Kathryn Campbell, has an undergraduate degree in psychology, a $\mathrm{PhD}$ in criminology, and a law degree. She is also the director of Innocence Ottawa, a student-run innocence project at the University of Ottawa. Campbell is thus extremely well suited to deal with the very complicated issues in law, psychology and the intersection of the two as they relate to wrongful convictions. This is best shown in the chapter on eyewitness identification, which is generally accepted to be the factor that is present more than any other in cases of wrongful conviction. The chapter presents in some detail the research by psychologists indicating the fallibility of human memory and then moves on to ways in which the identification process can be improved to reduce errors. Research has shown that presenting photos sequentially rather than simultaneously tends to lead to fewer false identifications. Having discussed this, the author then notes that some jurisdictions now require that photo lineups be done this way. Campbell also describes both American and Canadian case law related to the issue of eyewitness identification. She raises the complex issue of whether juries should hear from experts about the problems with eyewitness identification. Some people feel that juries must be warned about relying too much on an eyewitness, but others feel that having an expert testify about it goes too far. Campbell points out that American courts often allow expert testimony on this while Canadian courts rarely if ever 
do. This is an excellent discussion of the research and issues related to eyewitness identification. Campbell is to be congratulated for this chapter.

The chapter on forensic and other expert testimony also reflects the author's knowledge of law, psychology and research methods. The various kinds of forensic evidence are described in some detail, with their weaknesses highlighted and made more forceful by the use of examples from actual Canadian cases. The issues are pretty much the same in all of them. There is a lack of scientific rigour in the testing and even more important, almost no systematic demonstrations that the tests are valid or reliable. For example, firearm experts claim that they can tell what gun fired a particular bullet, but this claim is rarely if ever subject to random testing. If they were given twenty bullets from twenty different guns, could they really match bullets with guns? Maybe they could, but there is no convincing evidence to support this. Hair analysis is even more questionable and is now largely replaced by DNA analysis. The discussion makes it clear that with a few exceptions, forensic evidence must be relied on with caution. It is well established that inaccurate or overstated forensic evidence is one of the most prevalent factors that lead to wrongful convictions.

I should mention that there is another side to this issue. Some prosecutors and crowns complain that TV programs such as CSI have made jurors expect strong forensic evidence in every case. When there is no such evidence, it has become (they say) hard to get convictions. On the other hand, CSI has also probably made jurors believe even more in the value of forensic evidence and rely on it more than they should.

One omission in the chapter is that there is little discussion of the role played by bias on the part of forensic experts. Most of the forensic laboratories are run by police forces and even if they are independent most of their work comes from the police or the crown rather than from the defence. Because of this, those working in the labs may have a tendency, deliberate or inadvertent, to favour the prosecution. Certainly this has been shown in many cases, in which the forensic experts tend to overstate the evidence against the accused. It was one of the major reasons Guy Paul Morin was wrongly convicted. Despite giving bias too little attention, this is a very good chapter.

A positive feature of the book is that it deals with cases other than just murder. Most of those involved in innocence projects, including Innocence Canada, focus almost entirely on wrongful convictions for murder. This is because they are presumably the worst miscarriages of justice, and because typically those convicted are still incarcerated which is not true for most other crimes. But it is almost certain that the vast majority of wrongful convictions are for lesser crimes, partly because there are so many more of them and partly because legal counsel is typically less involved and perhaps less skilled. Most of those accused of theft or minor assault and other such crimes cannot afford their own lawyers. They will often confess just to get it over with, especially if they are minors who are told they can go home to their parents. These instances of wrongful conviction collectively may do far greater harm than the relatively few cases involving murder, but these lesser cases are rarely litigated or even noticed. While this book does not spend much time on them either, at least it mentions some of them in the tables. 
While many of the topics are covered well, there are some problems with the book. The writing is complicated and rather heavy. This is reinforced by the format and structure provided by the publisher. The text takes up full pages interrupted by only a few tables and no illustrations or photos. Unfortunately, all of this makes for hard going.

On a more substantive issue, I think the choice of "miscarriage of justice" rather than "wrongful convictions" is a mistake. The author makes an argument for the term she chose, but I believe that for most people miscarriages of justice can include all sorts of cases other than conviction when the person was innocent. Inadequate counsel, biased juries, improper interviews, and all sorts of other factors that end in a conviction may taint the verdict and make it a miscarriage of justice even if the accused did commit the crime. Moreover, improper sentences, unreasonable denial of parole, unjustified arrests, and lengthy detentions are all miscarriages of justice that have nothing to do with the focus of the book.

A notable omission in sections dealing with the causes of wrongful convictions is that there is too little attention spent on the role of prejudice and bias. The courts have acknowledged that jurors may be biased against black people, Indigenous people, those of varying sexual orientations - indeed against any minority group that is the object of discrimination. It is also the case that the police may be influenced by bias in whom they target as likely criminals and whom they then focus on as they pursue their investigation. It might have been useful to point out as just one example that is especially relevant in Canada the disparity in incarceration rates between Indigenous and others. Indigenous men are far more likely to be in prison than white men, and the difference is even greater for women, with Indigenous women being ten times as likely to be incarcerated. Similar but smaller disparities exist for other minority groups compared to whites. This factor is difficult to identify once a trial is finished but it surely plays a role in many wrongful convictions.

I would like to have seen more attention paid to the difference between Canadian and American systems as they relate to wrongful convictions. There is a drastic difference in how jurors are chosen. In Canada ordinarily prospective jurors are asked no questions. If the judge allows it, they can be questioned about possible bias. But the questioning is very limited, with just a few or even just one question allowed. In contrast, American courts allow extensive questioning about all sorts of issues. This makes jury selection much more complex in the United States. Yet there is no evidence that American juries are fairer and less biased than Canadian ones.

Another difference relating to how wrongful convictions are overturned in the two countries is the role of DNA. The Innocence Project is the most successful and well-known organization in the United States working to reverse wrongful convictions. It deals exclusively with exonerations through DNA testing and has managed to get hundreds of exonerations (and in some cases to confirm guilt) through up-to-date DNA analysis. Similar organizations in Canada rarely deal with DNA. Innocence Canada has had only a few cases in which DNA was a key issue. It seems that at least in the past Canadian investigators, police and others, have been more scrupulous in testing whatever samples are available. Perhaps with more and more knowledge of the usefulness of DNA analysis, this will change and courts in both countries will be certain to do whatever tests are possible. 
Finally, it would have been useful to have a discussion of how wrongful convictions are reversed. It could have been made clear that it is a long, complex and tedious process. Once someone has been convicted, in practice if not in law, the burden of proof of innocence shifts. An appeals court or the federal CCRG has to be convinced that the person was wrongly convicted. It is not sufficient to raise some doubt, because considerable deference is given to the verdict in the original trial. Thus, the typical exoneration takes many years during which the convicted person usually remains in prison. Those interested in wrongful convictions would have benefited from a description of this process.

As a hopeful aside, after this book was published, the Attorney General and Justice Minister of Canada announced that one of his top priorities would be the establishment of a federal commission to deal with wrongful convictions. This would be a big step forward since now identifying cases and trying to get them reversed has fallen to various non-profit groups. This should be the job of the federal government. It would be great if this were to occur.

In sum, despite some weaknesses, this is a good introduction to the field of wrongful convictions. It is a serious, scholarly book that relies on legal, psychological, and criminological research. There are 54 pages of notes and 27 pages of bibliography. The book deals with all of the issues well. It highlights the problem of wrongful convictions, describes in considerable detail the causes of these miscarriages of justice, and then to some extent discusses what remedies might be possible. There are no easy answers and it is to her credit that Campbell does not offer any. Rather she spells out the current situation and provides some ways in which it might get better. Because it is a somewhat difficult read, the book seems most appropriate as an overall introduction to the area for students and perhaps law students. Scholars may also find it useful since it covers so much material. It is certainly a substantial contribution to the field. 